\title{
Upaya Pencapaian Swasembada Pangan Melalui Membumikan Padi Amfibi Balitbangtan di Provinsi Papua Barat
}

Sostenes Konyep ${ }^{1 *}$

${ }^{1}$ Balai Pengkajian Teknologi Pertanian Provinsi Papua Barat

\begin{tabular}{l}
\hline \multicolumn{1}{c}{ ARTIKEL INFO } \\
\hline Sejarah artikel \\
Diterima $19 / 11 / 2020$ \\
Diterima dalam bentuk revisi 09/12/2020 \\
Diterima dan disetujui 11/12/2020 \\
Tersedia online 23/12/2020 \\
\hline Kata kunci \\
Upaya \\
Pencapaian \\
Swasembada pangan \\
Padi amfibi Balitbangtan \\
Papua Barat \\
\hline
\end{tabular}

\begin{abstract}
ABSTRAK
Sektor pertanian berperan penting karena berkontribusi sebagai penyedia bahan pangan dan bahan baku industri, penyumbang produk domestik bruto, penghasil devisa negara, penyerap tenaga kerja, sumber pendapatan utama masyarakat desa, penyedia bahan pakan dan energi,serta perannya dalam upaya menurunkan gas rumah kaca. RPJMN tahap -3 adalah lanjutan dari RPJMN tahap -2 (2010-2014) yang sudah berakhir yang mana salah satu upaya yang dilakukan adalah peningkatan swasembada padi, jagung dan kedelai. Dibutuhkan langkah-langkah konkrit untuk mencapai swasembada pangan diantaranya perencanaan dan implementasi program secara baik dan benar. Badan pusat statistik Provinsi Papua Barat menyatakan bahwa pertanian Papua Barat belum menunjukan perkembangan yang berarti. Produksi tanaman padi (baik ladang maupun sawah) ditahun 2018 menghasilkan sebanyak $14.035,0$ ton pada lahan seluas 4.892 ha dengan produktifitas 2,9 ton/ha. Di banding tahun sebelumnya terjadi penurunan produksi padi. Produksi padi tahun 2017 sebesar 27.593 ton. Penggunaan benih varietas unggul baru (VUB) merupakan konsep dasar PTT untuk meningkatkan produktivitas dan mengurangi dampak dari serangan hama. VUB padi amfibi Balitbangtan merupakan salah satu strategi Kementerian Pertanian dalam menghadapi dampak dari perubahan iklim berupa banjir dan kekeringan. Data kegiatan keji terap inovasi teknologi VUB padi amfibi yang dilakukan di distrik Prafi (Kampung Handuk dan Kampung Kerenu) di banding padi lokal 100 malam (data BPS Kabupaten Manokwari) memperlihatkan terdapat selisih produksi sekitar 2,8 ton/ ha lebih. Penyebaran dan perluasan areal pertanaman padi amfibi Balitbangtan di Provinsi Papua.
\end{abstract}

(C) 2020 Politeknik Pembangunan Pertanian Manokwari 


\section{ABSTRACT}

The agricultural sector plays an important role because it contributes as a provider of food and industrial raw materials, a contributor to gross domestic product, a foreign exchange earner, an absorber of labor, the main source of income for rural communities, a provider of feed and energy, and its role in efforts to reduce greenhouse gases. RPJMN stage -3 is a continuation of RPJMN phase -2 (2010-2014) which has ended, where one of the efforts made is to increase self-sufficiency in rice, corn and soybeans. It takes concrete steps to achieve food self-sufficiency, including planning and implementing the program properly and correctly. Good planning will result in the availability of accurate data. The West Papua Provincial Statistics Agency states that West Papua agriculture has not shown significant progress. Rice production in 2018 produced 14,035.0 tonnes on an area of 4,892 ha with a productivity of 2.9 tonnes / ha. Compared to

\section{PENDAHULUAN}

Sektor pertanian merupakan sektor penting dalam pembangunan ekonomi nasional sesuai RPJMN (rencana pembangunan jangka menengah nasional) tahap 3 (2015-2019). Sektor pertanian berperan penting karena kontribusinya sebagai penyedia bahan pangan dan bahan baku industri, penyumbang produk domestik bruto, penghasil devisa negara, penyerap tenaga kerja, sumber utama pendapatan masyarakat di pedesaan, penyedia bahan pakan dan energi, serta perannya dalam upaya menurunkan emisi gas rumah kaca. RPJMN tahap 3 adalah lanjutan dari RPJMN tahap 2 (2010-2014) yang sudah berakhir yang mana salah satu upaya yang dilakukan adalah peningkatan swasembada padi, jagung dan kedelai (Rencana Strategis Kemeterian Pertanian Tahun 2015-2019).

Kamus besar Bahasa Indonesia memberikan pengertian swasembada sebagai usaha mencukupi kebutuhannya sendiri. Menurut lembaga pertanian dan pangan dunia the previous year, there was a decrease in rice production. Rice production in 2017 was 27,593 tonnes. The use of new improved variety seeds (VUB) is the basic concept of PTT to increase productivity and reduce the impact of pest attacks. Amphibious Paddy Balitbangtan VUB is one of the strategies of the Ministry of Agriculture in the impact of climate change in the form of floods and drought. Data on the heinous activity of VUB technology innovation for amphibious rice carried out in Prafi district (Kampung Handuk and Kampung Kerenu) compared to 100 nights local rice (BPS data for Manokwari Regency) there is a production difference of about 2.8 tons / ha more. The spread and expansion of the amphibious rice planting area for Balitbangtan in West Papua Province by BPTP is expected to meet the government's expectations for food self-sufficiency.

(FAO) 1984 suatu negara dikatakan swasembada pangan jika produksinya mencapai 90\% dari kebutuhan nasional. Dibutuhkan langkah-langkah konkrit dalam pencapaian swasembada pangan diantaranya perencanaan dan implementasi program secara baik dan benar. Perencanaan yang baik akan menghasilkan ketersediaan data yang akurat (Heriawan R, 2016).

Sementara itu Badan pusat statistik Provinsi Papua Barat menyatakan bahwa pertanian Papua Barat belum menunjukan perkembangan yang berarti. Berdasarkan nilai produksinya, tanaman padi (baik ladang maupun sawah) ditahun 2018 menghasilkan sebanyak 14.035,0 ton pada lahan seluas 4.892 ha dengan produktifitas 2,9 ton/ha. Di banding tahun sebelumnya terjadi penurunan produksi padi. Produksi padi tahun 2017 sebesar 27.593 ton. Jika dibanding dengan potensinya yang dapat mencapai 6-7 ton/ha, angka produktivitas ini di nilai masih rendah. Rendahnya produktivitas padi menurut Makarim et.al 
(2004) berkaitan dengan penggunaan varietas unggul baru (VUB).

Konsep PTT (Pengendalian Tanaman Terpadu) memiliki komponen dasar yang harus dipenuhi yakni penggunaan varietas unggul baru (VUB) untuk meningkatkan produktivitas dan mengurangi dampak dari serangan hama penyakit pada tanaman padi. Meningkatnya produktivitas padi persatuan luas maka secara tidak langsung akan meningkatkan pendapatan, didalam satuan luas kelompok tani akan meningkatkan kesejahteraannya dan secara nasional akan membantu meningkatkan produktivitas menuju swasembada beras.

\section{POTENSI SUMBERDAYA LAHAN DI PAPUA BARAT}

Badan pusat statistik Papua Barat (2014) menyebutkan bahwa luas wilayah Provinsi Papua Barat $138.358 \mathrm{~km}^{2}$, kawasan hutan dengan luasan $97.239 \mathrm{~km}^{2}$, sekitar 9,9 juta hektar sangat berpotensi untuk pembangunan pertanian dalam arti luas dan seluas ,7 juta ha berpotensi untuk tanaman pangan dan hortikultura. Terlihat bahwa potensi lahan yang baru di manfaatkan sekitar $33 \%$.

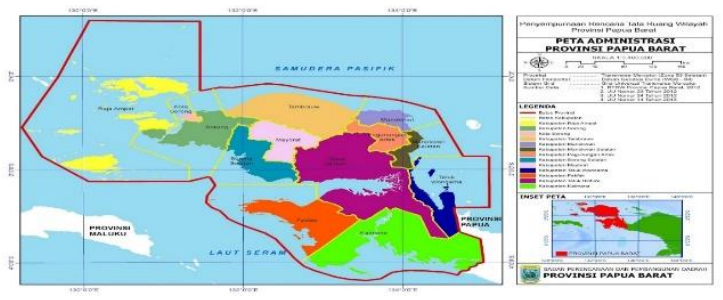

Gambar 1. Peta Provinsi Papua Barat

Kesesuaian lahan menurut Raden, et al., (2010) sebenarnya kelas sedikit sesuai (S3/sesuai marginal) untuk sawah dataran rendah dan juga padi ladang kepatuhan dapat ditingkatkan melalui upaya untuk meningkatkan dengan menambahkan materi organik, pemupukan, pengapuran, drainase, terasering dan guludan sehingga potensi lahan kelas kesesuaian menjadi sangat cocok (S2/ cukup sesuai).

Kebutuhan beras sebagai sumber utama pangan penduduk Indonesia terus meningkat. Laju pertambahan penduduk sekitar $2 \%$ pertahun dan perubahan pola konsumsi masyarakat dari non beras ke beras menyebabkan kebutuhan manusia akan beras pun bertambah. Disis lain, terjadi penciutan lahan sawah irigasi subur (intensif) akibat konservasi lahan untuk kepentingan non pertanian dan munculnya fenomena degradasi kesuburan lahan mengakibatkan produktivitas padi sawah irigasi cenderung melandai (Leveling off). Berkaitan dengan prakiraan terjadinya penurunan produksi maka perlu diupayakan penanggulangannya melalui peningkatan produktivitas lahan sawah yang ada, pencetakan lahan irigasi baru dan pengembangan lahan potensial lain didalamnya lahan kering (Supriansyah et al., 2013).

Padi adalah komoditas tanaman pangan yang penting. Seiring berjalannya waktu, telah terjadi penyempitan lahan sawah irigasi karena konversi lahan untuk kepentingan non pertanian sehingga salah satu upaya yang dapat dilakukan adalah penggunaan varietas unggul padi ladang dengan menggunakan jarak tanam yang tepat (Sihotang et al., 2014). 


\section{LUAS PANEN BERDASARKAN DISTRIK}

\section{KABUPATEN MANOKWARI}

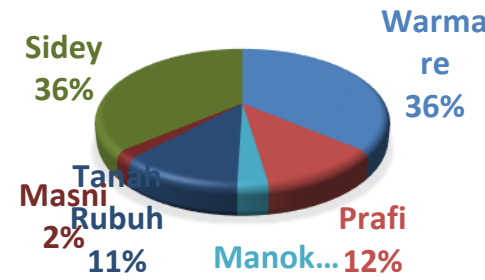

Gambar 2. Luas Panen Berdasarkan Distrik di Kabupaten Manokwari

Penghasil padi ladang terbesar adalah Kabupaten Manokwari dengan luas panen sebesar 36,06\% dari total luas wilayah Provinsi Papua Barat. Penurunan produksi tahun 2013, 2014 dan 2015 dari tahun 2012 disebabkan oleh penurunan produksi padi ladang sebesar 1,23 ribu ton atau $39,14 \%$

\section{PERUBAHAN IKLIM DAN DAMPAK TERHADAP KETAHANAN PANGAN}

Meningkatnya emisi/pelepasan gas rumah kaca akibat kegiatan manusia menyebabkan terjadinya pemanansan global diiringi perubahan iklim. Dampaknya dapat terlihat dari perubahan pola hujan, penigkatan suhu udara dan naiknya permukaan air laut. Meningkatnya intensitas maupun frekuensi banjir dan kekeringan merupakan contoh perubahan pola hujan.

Pemicu laju peningkatan konsentrasi GRK di atmosfer adalah bagian dari beragam kegiatan manusia di sektor industri, energi, kehutanan, transportasi, pertanian dan perubahan penggunaan lahan. GRK umumnya terdapat dalam bentuk karbon dioksida $\left(\mathrm{CO}_{2}\right)$, metan $\left(\mathrm{CH}_{4}\right)$, dinitrogen-oksida $\left(\mathrm{N}_{2} \mathrm{O}\right)$, sulfurheksaflorida $\quad\left(\mathrm{SF}_{6}\right), \quad$ perflorokarbon
(PFCs) dan hidroflorokarbon (HFCs). Gas itu menyebabkan naiknya suhu udara, sebagai akibatnya panas atmosfer bumi meningkat kemudian memicu pemanasan global.

Kontribusi sektor pertanian terhadap emisi GRK relatif kecil, tetapi sub sektor tanaman pangan mengalami dampak cukup besar karena perubahan cuaca ekstrim yang menyebabkan banjir dan kekeringan dapat menurunkan produksi secara nyata. Faktor utama perubahan iklim global yang berdampak terhadap sektor pertanian antara lain: 1) perubahan pola hujan dan iklim ekstrim (banjir dan kekeringan), 2) meningkatnya suhu udara dan 3) peningkatan permukaan air laut. Boer (2009), memperkirakan bila kenaikan $\mathrm{CO}_{2}$ tidak diperhitungkan, dampak pemanasan global dan perubahan iklim di Indonesia dapat menurunkan produksi padi di Jawa sebesar 1,8 juta ton pada tahun 2025 dan 3,6 juta ton pada tahun 2050. Bila dihitung dengan konversi lahan yang sulit di bending, penurunan produksi padi bisa menjadi lebih tinggi lagi sekitar 5 juta ton tahun 2025 dan 10 juta ton pada tahun 2050.

Tebel 1. Varietas padi toleran kekeringan dan genangan (amfibi)

\begin{tabular}{ccccc}
\hline No & Varietas & $\begin{array}{c}\text { Umur } \\
\text { (HSS) }\end{array}$ & $\begin{array}{c}\text { Potensi } \\
\text { Hasil } \\
\text { t/ha }\end{array}$ & $\begin{array}{c}\text { Tekstur } \\
\text { nasi }\end{array}$ \\
\hline 1 & Limboto & 1255 & 6,0 & Sedang \\
2 & Batutegi & 120 & 6,0 & Pulen \\
3 & Towuti & 115 & 7,0 & Pulen \\
4 & Situpatengg & 120 & 6,0 & Sedang \\
& ang & & & Sedang \\
5 & Situbagendi & 120 & 6,0 & Pulen \\
& t & & & \\
6 & Inpari 10 & 112 & 7,0 & Pulen \\
& Laeya & & & Sangatpule \\
7 & Inpago 4 & 124 & 6,1 & $\mathrm{n}$ \\
8 & Inpago 5 & 118 & 6,2 & Sangatpule \\
& & & & $\mathrm{n}$ \\
9 & Inpago 6 & 118 & 6,2 & Pulen \\
& & & & Pulen \\
10 & Inpago 7 & 111 & 7,4 & sedang \\
11 & Inpago 8 & 119 & 8,1 & sedang \\
12 & Inpago 9 & 109 & 8,4 & 6,0 \\
13 & Inpago 11 & 111 & &
\end{tabular}


Dalam mengantisipasi dampak keberagaman dan perubahan iklim, Kementerian Pertanian telah mempersipkan strategi antisipasi berupa : penyediaan varietas unggul berdaya hasil tinggi dan toleran kekeringan dengan karakteristik a) umur sangat genjah agar terhindar (escape strategy) dari kondisi ancaman kekeringan dan b) varietas unggul padi yang tahan atau adaptif terhadap kondisi kekeringan (tolerant strategy) dan tahan pada dua kondisi iklim yang berbeda yaitu kondisi kering dan kondisi kebasahan. Tabel 1 memperlihatkan varietas padi toleran kekeringan dan genangan (amfibi) Badan Litbang Pertanian.

\section{PENERAPAN PTT PADI LADANG AMFIBI BADAN LITBANG PERTANIAN}

Suatu pendekatan inovatif dan dinamis dalam upaya meningkatkan produksi dan pendapatan petani melalui perakitan komponen teknologi secara parsitipatif bersama petani disebut Pengelolaan Tanaman Terpadu (PTT). Prinsip utama penerapan PTT padi ladang amfibi:

a) Terpadu: sumberdaya tanaman, tanah dan air di kelola dengan baik secara terpadu

b) Sinergis : Pemanfaatn teknologi terbaik, memperhatikan keterkaitan Antara komponen teknologi yang saling mendukung

c) Spesifik lokasi : Memperhatikan kesesuaian teknologi dengan lingkungan fisik, sosial budaya, dan ekonomi petani d) Partisipatif : Petani berperan aktif memilih dan menguji teknologi yang sesuai dengan kondisi setempat, dan meningkatkan kemampuan melalui proses pembelajaran (Petunjuk Teknis PTT Padi Gogo, Suriansyah dkk, Badan Litbang pertanian. BPTP Kalimantan tengah.

Berdasarkan keadaan di lapangan bahwa penyebaran VUB padi lahan kering di Provinsi Papua Barat belum seluruhya merata, dikarenakan beberapa hal diantaranya, petani masih mempertahankan dan menggunakan varietas yang sudah tidak dianjurkan lagi untuk ditanam, tetapi masih saja menanamnya walaupun dengan resiko gagal panen karena serangan hama dan penyakit. Selain itu, petani sangat lambat dalam menerima teknologi baru yang diberikan. Petani akan menerima teknologi baru, apabila mereka telah yakin mengetahui gambaran secara nyata tentang keberhasilan teknologi baru yang diterima

Penanaman beberapa varitas padi ladang belum mempengaruhi pertumbuhan dan hasil padi ladang. Pengolahan tanah dan pemberian mulsa berpengaruh terhadap pertumbuhan padi ladang. Perlakuan pengolahan tanah dengan mulsa jerami 4 t/ha, memberikan pertumbuhan dan hasil padi ladang yang lebih baik dari perlakuan lainnya Pertumbuhan dan produksi padi ladang di lahan kering sangat dipengaruhi oleh ketersediaan sumberdaya air akibat jumlah dan distribusi hujan yang tidak merata. Hal ini menyebabkan kebutuhan air tidak akan terpenuhi.

Balai Besar Padi (2017) mengemukakan bahwa air merupakan salah satu input yang sangat penting bagi sistem produksi padi sawah 
yang mengkonsumsi air lebih banyak dibandingkan bila ditanam di luar lahan sawah yang tidak selalu digenang. Ketersediaan air tidak hanya mempengaruhi produktivitas tanaman, luas areal tanam dan intensitas pertanaman, melainkan juga berengaruh terhadap potensi perluasan areal baru, bahkan menentukan kualitas produksi gabah. Terminologi amfibi ini digunakan juga untuk menunjukkan kemampuan tumbuh beberapa varietas padi yang dapat beradaptasi dengan baik pada kondisi lahan kering (gogo) maupun lahan basah (sawah). Varietas padi yang memiliki kemampuan tumbuh di dua kondisi tersebut kemudian disebut sebagai padi amfibi.

Potensi produksi dan produktivitas hasil panen padi ladang amfibi Badan Litbang Pertanian apabila dibandingkan dengan padi ladang 100 malam (varietas lokal) di Kabupaten Manokwari dapat diamati pada tabel 2 berikut ini:

Tabel 2. Potensi Hasil Panen Padi Ladang Amfibi dan Padi lokal di Kabupaten Manokwari

\begin{tabular}{llll}
\hline No & \multicolumn{1}{c}{$\begin{array}{c}\text { Nama } \\
\text { Varietas }\end{array}$} & $\begin{array}{c}\text { Perkiraan } \\
\text { Produksi } \\
\text { Per Ha }\end{array}$ & Keterangan \\
\hline 1 & Towuti & 7,52 & Rebah/rusak \\
2 & Inpago 4 & - & \\
3 & Inpago 8 & 8,8 & \\
4 & Inpago 9 & 5,47 & \\
5 & Inpago 11 & 5,44 & \\
6 & Lokal 100 & 2,74 & \\
& malam & & \\
\hline
\end{tabular}

Dari tabel diatas terlihat produksi padi lokal 100 malam sebesar 2,74 ton/ha dengan produksi sebesar 2,6 ton/ha terdapat selisih sekitar 2,8 ton/ha. Artinya padi ladang ampibi cocok dan dapat dikembangkan di masyarakat Provinsi Papua Barat. Selisih produksi ini disebabkan karena penerapan PTT usahatani dalam penanaman padi ladang ampibi pada kegiatan kaji terap BPTP Papua Barat. Potensi nilai peningkatan pendapatan petani akan diperoleh dari pemasaran benih padi kepada petani lain dengan nilai jual Rp. $7.000 / \mathrm{kg}$ atau dengan bisa dipasarkan dalam bentuk beras senilai Rp. 12.000/kg. Penanaman padi ladang kegiatan kaji terap inovasi teknologi di Kampung Handuk memperhatikan dan melaksanakan 4 aspek usahatani dengan yaitu: a). penggunaan varietas unggul, b). Pemberian bahan organik, c). Pemupukan berimbang berdasar unsur hara tanah dan kebutuhan tanaman dan d) Pengendalian hama terpadu.

Heriawan $\mathrm{R}$ menyatakan bahwa untuk peningkatan produktivitas padi, maka faktor utama yang mempunyai pengaruh adalah penerapan teknologi pertanian sesuai anjuran teknologi Pengelolaan Tanaman Terpadu (PTT) yang diperkenalkan sejak 17 tahun yang lalu. Dalam PTT, petani diajak untuk menerapkan komponen teknologi dasar dan teknologi pilihan, diantaranya introduksi sistem tanam Jajar Legowo (Jarwo) dan varietas unggul baru (VUB) padi. Disisi lain, Badan Litbang Pertanian telah menghasilkan beragam varietas padi yang telah didiseminasikan kepada petani secara berkelanjutan termasuk melalui program SL-PTT dan bantuan benih.

Menurut Suyamto et al. (2007) varietas unggul merupakan salah satu teknologi yang berperan penting dalam peningkatan kuantitas dan kualitas produk pertanian. Kontribusi nyata varietas unggul terhadap peningkatan produksi padi nasional antara lain tercermin dari pencapaian swasembada beras pada tahun 1984 . 
Hal ini terkait dengan sifat-sifat varietas unggul padi ladang antara lain berdaya hasil tinggi, tahan terhadap penyakit utama, umur genjah sehingga sesuai untuk di kembangkan dalam pola tanam tertentu, dan rasa nasi enak (pulen) dengan kadar protein relative tinggi. Sistem tanam larikan gogo 2:1 dengan jarak 40:20:10.

Pemupukan menggunakan PUTK, hal ini selaras dengan hasil kajian Ernawati (2013) dalam Hafif (2016) dimana penanaman varietas unggul baru dapat meningkatkan produktivitas padi ladang dari 3 t/ha menjadi 4,5-5 t/ha.

Penggunaan berbagai varietas unggul baru spesifik lokasi, serta pendampingan terhadap aplikasi teknologi pengelolaan lahan seperti penggunaan pembenah tanah, sistem tanam jajar legowo, dan pemupukan, peningkatan produksi padi dapat dipenuhi dari pengembangan padi ladang di lahan kering suboptimal (Hafif, 2016). Kinerja padi ladang ampibi diharapkan dapat meningkatkan produktivitas padi di Provinsi Papua Barat.

Pemupukan yang dilaksanakan pada kegiatan kaji terap inovasi teknologi pertanian BPTP Papua Barat berdasarkan pada hasil uji PUTK (perangkat uji tanah kering) dan dihasilkan rekomendasi pemupukan pupuk urea sebanyak 102,17 kg/ha dan pupuk phonska sebanyak $300 \mathrm{~kg} / \mathrm{ha}$. Pemupukan dilaksanakan sebanyak dua kali pada usia padi 21 hari yang bertujuan untuk meningkatkan kesuburuan tanah, agar padi bisa bertambah jumlah anakan, memiliki batang padi yang kokoh serta jumlah daun yang maksimal dan pemupukan ke dua dilaksanakan pada saat padi usia 56 hari dengan tujuan agar proses pengisian bulir padi bisa maksimal.
Kombinasi pemupukan secara signifikan mempengaruhi tinggi tanaman, jumlah malai, dan panjang malai, tetapi tidak berat mempengaruhi signifikan 1000 butir dan bijibijian kering. Inpago 4 adalah varietas terbaik. Pupuk NPK terbaik ditemukan pada dosis 250 kg/ha (Nazirah L dan Damanik BSJ. 2015).

Dari hasil penelitian tersebut diketahui bahwa salah satu faktor yang berpengaruh pada peningkatan produksi dan produktivitas padi ladang ampibi di KP Anday adalah penggunaan pupuk berimbang. Pupuk yang diberikan tepat jenis yaitu urea dan phonska, kemudian tepat dosis sesuai anjuran hasil uji PUTK dan tepat waktu yaitu diberikan pada masa padi berumur 21 hari dan umur padi 56 hari sesuai dengan tujuan yang ingin dicapai dengan pemupukan.

Berikut ini tabel kondisi tinggi tanaman dan jumlah anakan per rumpun seperti tertera dibawah ini:

Tabel 3. Tinggi tanaman dan jumlah anakan, panjang malai dan jumlah biji 5 varietas padi amfibi Balitbangtan

\begin{tabular}{llllll}
\hline No & $\begin{array}{c}\text { Nama } \\
\text { Varietas }\end{array}$ & $\begin{array}{c}\text { Tinggi } \\
\text { Tanaman }\end{array}$ & $\begin{array}{c}\text { Panjang } \\
\text { Malai }\end{array}$ & $\begin{array}{c}\text { Jumlah } \\
\text { Anakan }\end{array}$ & $\begin{array}{l}\text { Jumlah } \\
\text { Biji }\end{array}$ \\
\hline 1 & Towuti & $60 \mathrm{~cm}$ & $17-19 \mathrm{~cm}$ & $\begin{array}{l}20-27 \\
\text { anakan }\end{array}$ & $260-270$ \\
2 & Inpago 9 & $160 \mathrm{~cm}$ & $17-26 \mathrm{~cm}$ & $\begin{array}{l}14-17 \\
\text { anakan }\end{array}$ & $240-260$ \\
3 & Inpago 8 & $152 \mathrm{~cm}$ & $24-29 \mathrm{~cm}$ & $\begin{array}{l}19-24 \\
\text { anakan } \\
12-15\end{array}$ & $240-270$ \\
4 & Inpago 4 & $164 \mathrm{~cm}$ & $22-26 \mathrm{~cm}$ & $\begin{array}{l}12-15 \\
\text { anakan } \\
12-19 \\
\text { anakan }\end{array}$ & $372-386$ \\
5 & Inpago & $178 \mathrm{~cm}$ & $25-27 \mathrm{~cm}$ & & \\
\hline
\end{tabular}

\section{PENYEBARAN BENIH PADI AMFIBI} BALITBANGTAN DI PAPUA BARAT

Kepala Bidang tanaman pangan dan hortikultura Kabupaten Manokwari, Ir. Bob Pattikawa dalam Rapat Kooordinasi dan Evaluasi Upsus Pajale Provinsi Papua Barat menuturkan bahwa produktivitas padi di 
Kabupaten Manokwari rendah. Hal ini diakibatkan penggunaan benih unggul bersertifikat yang di gunakan petani hanya sekitar 10\%, sisanya benih yang tidak bersertifikat dan yang sudah berulang-ulang ditanami.

Untuk itu BPTP Balitbangtan Papua Barat dalam berbagai event seperti pameran Balitbangda Provinsi, pameran PEDA IV KTNA Provinsi, dan temu teknis penyuluh di beberapa BPP, telah memperkenalkan dan menyebarkan benih varietas padi amfibi Balitbangtan ke berbagai wilayah di Provinsi Papua Barat. Harapannya dapat membantu petani dalam menghadapi persoalan yang di hadapi terkait benih varietas unggul dan bersertifikat.

Benih varietas unggul padi amfibi Balitbangtan sudah disebar ke beberapa daerah di Provinsi Papua Barat antara lain : Kabupaten Manokwari, Kabupaten Tambraw, Kabupaten Sorong, Kabupaten Raja Ampat, Kabupaten Teluk Bintuni dan Kabupaten Manokwari Selatan.

Pengembangan padi ladang ampibi yang dilakukan oleh BPTP diharapkan dapat menjadi awal dari peningkatan ketahanan pangan masyarakat. Kegiatan ini mempunyai karakteristk antara lain: berskala kecil, dimiliki oleh individu atau keluarga, menggunakan teknologi yang sederhana, bersifat padat tenaga kerja, pendidikan dan keahlian tenaga kerja rendah dan tingkat upah yang relatif rendah pula (Bappenas, 2009). Hasil produksi dari padi ladang ampibi diharapkan dapat bermanfaat bagi masyarakat baik secara langsung maupun tidak langsung.
Pengembangan padi ke lahan kering akan menghadapi tantangan persaingan dengan komoditas lain, terutama ubi kayu, jagung, dan tanaman industri. Agar dapat bersaing, produktivitas padi ladang harus ditingkatkan dengan menggunakan varietas unggul baru seperti Inpago 8, perbaikan cara pengelolaan lahan seperti aplikasi pembenah tanah, sistem tanam jajar legowo dan perbaikan pemupukan sehingga produktivitas padi ladang meningkat sampai 5 ton/ha (Hafif, 2016).

Menurut Sulaiman A, untuk pencapaian swasembada pangan, benih merupakan sarana yang sangat penting dalam produksi pertanian. Ketersediaan benih dalam jumlah, kualitas, dan ketepatan waktu yang memadai menjadi penentu keberhasilan usaha pertanian. Arah dan kebijakan program perbenihan untuk peningkatan produksi, produktivitas, dan mutu hasil pertanian semula lebih diprioritaskan pada tanaman pangan utama, yakni pada padi, jagung, dan kedelai. Tetapi untuk mencapai target swasembada pangan, dan peningkatan produksi pertanian pemerintahan Jokowi-JK telah mencanangkan tahun 2018 sebagai tahun perbenihan dan mengalokasikan anggaran untuk bantuan benih unggul seluas 7 juta ha hingga tahun 2019, termasuk untuk perkebunan dan hortikultura.

\section{KESIMPULAN DAN SARAN}

Provinsi Papua Barat mempunyai potensi sumberdaya lahan yang masih sangat luas untuk pengembangan tanaman pangan khususnya padi ladang amfibi Balitbangtan. Pengembangan padi ladang amfibi Balitbangtan sesuai tatanan masyarakat lokal Papua Barat 
dan layak dikembangkan karena mempunyai produktivitas tinggi bila menerapkan panca usaha tani di banding varietas lokal 100 malam. Usaha tani padi ladang amfibi Balitbangtan dapat meningkatkan swasembada pangan di Provinsi Papua Barat.

\section{DAFTAR PUSTAKA}

Badan Litbang Pertanian. (2008). Pengelolaan Tanaman Terpadu (PTT) Padi Gogo. Departemen Pertanian, Jakarta.

Balai Besar Padi. (2017). Padi Ampibi Antisipasi Dampak Perubahan Iklim.http://bbpadi.litbang.pertanian.go. id/index.php/berita/infoaktual/content/432-padi-amfibiantisipasi-dampak-perubahan-iklim diakses 15 September 2019

Bappenas. (2009). Kajian Evaluasi Pembangunan Sektoral: Peran Sektor Informal Sebagai Katup Pengaman Masalah Ketenagakerjaan. Jakarta: Bappenas.

BPS. (2013). Analisis Sosial Ekonomi di Provinsi Papua Barat. Hasil Survei Pendapatan Rumah Tangga Usaha Pertanian. Sensus Pertanian.

BPS. (2016). Statistik Tanaman Pangan. BPS Kabupaten Manokwari.

BPS. (2017a). Potensi Ekonomi Manokwari. Sensus Ekonomi 2016 Analisis Hasil Listing. BPS Kabupaten Manokwari.

BPS. (2017b). Provinsi Papua Barat Dalam Angka 2017. BPS Provinsi Papua Barat. Manokwari.

BPS. (2019). Statistik Daerah Provinsi Papua Barat. BPS Provinsi Papua Barat. Manokwari.

Hafif, B. (2016). Optimasi Potensi Lahan Kering Untuk Peningkatan Produksi Padi Satu Juta Ton di Provinsi Lampung. JUrnal Litbang Pertanian Vol 35 No 2 Juni 2016. Bogor.

Heriawan R, Achmad S, Handewi P S, Mewa A, I Ketut Kariyasa \& Ranggga D Y.
(2016). Kebijakan Swasembada Pangan Berkelanjutan. IAARD Press. Jakarta.

https://www.kbbi.web.id/swasembada

Kastanja AY. (2010). Kajian Penerapan Teknik Budidaya Padi Ladang Varietas Lokal (Studi Kasus Pada 4 Kecamatan di Kabupaten Halmahera Utara). Politeknik Perdamaian Halmahera. Tobelo.

Kementerian Pertanian. (2015). Rencana Strategis Kementerian Pertanian Tahun 2015-2019. Kementerian Pertanian Republik Indonesia. Jakarta.

Kementerian Pertanian. (2015). Perubahan Iklim dan Inovasi Teknologi Produksi Tanaman Pangan. Badan Litbang Pertanian. Jakarta.

Lekitoo, M. (2011). Pembangunan Pertanian dan Perdesaan Dalam Perspektif Sosiologis di Papua Barat. Prosiding Seminar Nasional Akselerasi Pembangunan Pertanian dan Perdesaan Berbasis Inovasi. Universitas Negeri Papua. Manokwari.

Mustofa. (2012). Analisis Ketahanan Pangan Rumah Tangga Miskin dan Modal Sosial di Provinsi DIY. Jurnal Geomedia Sains Geografi. Vol 10 Nomor 1 Mei 2012. Jurusan Pendidikan Geografi. Universitas Negeri Yogyakarta

Nazirah, L \& Damanik, B.S.J. (2015). Pertumbuhan dan Hasil Tiga Varietas Padi Ladang Pada Perlakuan Pemupukan. Jurnal Floratek. Universitas Sumatera Utara. Medan.

Pemprov Papua Barat. (2017). Rencana Pembangunan Jangka Menengah Daerah Provinsi Papua Barat Tahun 2017-2022. Pemprov Papua Barat. Manokwari.

Raden I, Thamrin, Syarif F, Fadli \& Darmi. (2010). Evaluasi Kesesuaian Lahan Untuk Tanaman Padi dan Padi Ladang di Desa Bila Talang Kecamatan Tabang Kabupaten Kutai Kartanegara. Fakultas Pertanian. Universitas Kartanegara.

Sitohang, F.R.H., Siregar, L.A.M., \& Putri, L.A.P. (2014). Evaluasi Pertumbuhan 
dan Produksi Beberapa Varietas Padi Ladang (Oriza Sativa L) Pada Beberapa Jarak Tanam Yang Berbeda. Jurnal Online Agroekoteknologi. ISSN No 2337-6597. Vol 2 No 2 661-679. Maret. 2014

Sulaiman, A., Kasdi, S., Deciyanto, S., Sri Sulihanti, \& Suci, W. (2018). Kebijakan Penyelamat Swasembada Pangan. IAARD Press. Jakarta

Supriansyah, Suparman, Bhermana, A., \& Anto, A. (2013). Petunjuk Teknis Pengelolaan Tanaman Terpadu (PTT) Padi Ladang.BPTP (Balai Pengkajian Teknologi Pertanian) Kalimantan Tengah.

Suyamto, R. Hidajat, S. Wahyuni, \& Y. Samaullah. (2007). Pedoman Bercocok Tanam Padi. Badan Penelitian Dan Pengembangan Pertanian. Departemmen Pertanian.

Tulak, P., Paulina \& Dharmawan, Arya. (2009). Struktur Nafkah Rumahtangga Petani Transmigran : Studi Sosio-Ekonomi di Tiga Kampung di Distrik Masni Kabupaten Manokwari. Sodality: Jurnal Sosiologi Pedesaan. 3. 10.22500/sodality.v3i2.5866.

Undang-Undang Republik Indonesia. Nomor 18 Tahun 2012. Tentang Pangan.

Wibowo, K. (2012). Peranan Sektor Pertanian Dalam Perekonomian Kabupaten Manokwari. Jurnal Agrotek Vol 3 No 1 Januari 2012. Fakultas Pertanian. Universitas Papua.

Widati, A.W. (2015). Ketersediaan Pangan di Provinsi Papua Barat. Seminar Nasional. Kearifan Lokal Nilai Adiluhung Batik Indonesia Untuk Daya Saing Internasional. ISBN. 978-979-1230353. Universitas Islam Batik Surakarta.

Yunizar. (2014). Kajian Teknologi Hemat Air Pada Padi Ladang Pada Lahan Kering Masam Dalam Mengantisipasi Perubahan Iklim di Provinsi Riau. Prosiding Seminar Nasional lahan Suboptimal 2014. Palembang. ISBN. 979-587-529-9.
Yuminarti, Umi. (2017). Kebijakan Transmigrasi Dalam Kerangka Otonomi Khusus di Papua: Masalah dan Harapan. Jurnal Kependudukan Indonesia. Vol 12. No 1 Juni 2017. 